\title{
PENGARUH TINGKAT PENDIDIKAN, UMK, INVESTASI TERHADAP PENYERAPAN TENAGA KERJA DAN PERTUMBUHAN EKONOMI, KABUPATEN/KOTA DI PROVINSI BALI
}

\author{
Ida Bagus Agung Bayu windayana ${ }^{1}$ \\ Ida Bagus Darsana ${ }^{2}$ \\ Fakultas Ekonomi dan Bisnis Universitas Udayana (Unud), Bali, Indonesia ${ }^{1,2}$ \\ E-mail : bayuwindayanaa@yahoo.com
}

\begin{abstract}
The purpose of this study is to analyze the level of education, minimum wage, and investment on employment in the Province of Bali, to analyze the effect of education level, minimum wage, investment and labor absorption on economic growth in the Province of Bali, and to analyze the indirect effect of education level, minimum wage and investment in economic growth through employment of regencies / cities in Bali Province. This research was conducted in the regencies / cities of Bali Province in 2014-2018. The results of this study: (1) The level of education does not have a effect on employment in districts / cities of Bali Province, minimum wage have a positive effect on employment, investment has a negative effect on employment in districts / cities of Bali Province ; (2) The level of education has a positive effect on economic growth, minimum wage has a negative effect on economic growth, investment has no effect on economic growth, employment absorption has a direct effect on economic growth in districts / cities in Bali Province; (3) minimum wage has an indirect effect on economic growth through employment, as indicated by employment as an intervening variable. While the level of education and investment does not have an indirect effect on economic growth through employment, which is indicated by employment rather than as an intervening variable.
\end{abstract}

Key words: Level Of Education; Minimum Wage,; Invesment; Labor Absorption; and Economic Growth.

\begin{abstract}
ABSTRAK
Tujuan dari penelitian ini adalah untuk menganalisis tingkat pendidikan, UMK, dan investasi terhadap penyerapan tenaga kerja di Provinsi Bali, untuk menganalisis pengaruh tingkat pendidikan, UMK, investasi dan penyerapan tenaga kerja terhadap pertumbuhan ekonomi di Provinsi Bali, dan untuk menganalisis pengaruh tidak langsung tingkat pendidikan, UMK dan investasi terhadap pertumbuhan ekonomi melalui penyerapan tenaga kerja kabupaten/kota di Provinsi Bali. Penelitian ini dilakukan di Kabupaten/kota Provinsi Bali pada tahun 2014-2018. Hasil penelitian ini : (1) Tingkat pendidikan tidak berpengaruh terhadap penyerapan tenaga kerja, UMK berpengaruh positif terhadap penyerapan tenaga kerja, Investasi berpengaruh negatif terhadap penyerapan tenaga kerja di kabupaten/kota Provinsi Bali; (2) Tingkat pendidikan berpengaruh positif terhadap pertumbuhan ekonomi, UMK berpengaruh negatif terhadap pertumbuhan ekonomi, investasi tidak berpengaruh terhadap pertumbuhan ekonomi, penyerapan tenaga kerja berpengaruh langsung terhadap pertumbuhan ekonomi kabupaten/kota di Provinsi Bali; (3) UMK berpengaruh tidak langsung terhadap pertumbuhan ekonomi melalui penyerapan tenaga kerja yang ditunjukkan dengan penyerapan tenaga kerja sebagai variabel intervening. Sedangkan tingkat pendidikan dan investasi tidak berpengaruh langsung terhadap pertumbuhan ekonomi melalui penyerapan tenaga kerja yang ditunjukkan penyerapan tenaga kerja bukan sebagai variabel intervening.
\end{abstract}

Kata kunci: Tingkat Pendidikan; UMK; Investasi; Penyerapan Tenaga Kerja; dan Pertumbuhan Ekonomi. 


\section{PENDAHULUAN}

Salah satu tolak ukur penting dalam menentukan keberhasilan pembangunan ekonomi adalah pertumbuhan ekonomi yang menggambarkan suatu dampak nyata dari kebijakan pembangunan yang dilaksanakan. Pertumbuhan ekonomi memberikan wawasan mengapa pertumbuhan Negara pada tingkat yang berbeda dari waktu ke waktu, dan ini akan mempengaruhi pemerintah dalam membuat kebijakan (Darma, 2014). Menurut Akan dkk (2007), Sektor pariwisata dapat berkontribusi signifikan terhadap pertumbuhan ekonomi Bali. Untuk mencegah terjadinya pertumbuhan ekonomi yang menurun dan tingkat pengangguran yang tinggi pemerintah membuat kebijakan untuk merangsang pertumbuhan lapangan pekerjaan (Beard dkk., 2018). Berbagai kebijakan pemerintah diperlukan sebagai stabilator pertumbuhan ekonomi di Provinsi Bali (Yusuf \& Andy, 2015). Kebijakan pemerintah tersebut diantaranya kebijakan fiskal dan kebijakan moneter yang berperan penting dalam pertumbuhan ekonomi suatu Negara (Kotaskova dkk., 2018).

Penduduk yang bertambah dari waktu ke waktu dapat menjadi pendorong maupun penghambat pertumbuhan ekonomi. Menurut Todaro (2000:116) dalam BPS (2018), pertumbuhan penduduk dan pertumbuhan angkatan kerja dianggap sebagai salah satu faktor positif yang memacu pertumbuhan ekonomi. Jumlah tenaga kerja yang lebih besar akan menambah tenaga kerja produktif. Hal ini bisa terjadi apabila tenaga kerja produktif tersebut dapat terserap pada kesempatan kerja yang tersedia, dan akan menjadi masalah apabila pertumbuhan tenaga kerja jauh melebihi kesempatan kerja yang tersedia. Menurut Ganie (2017), penyerapan 
tenaga kerja oleh perusahaan, umumnya didasarkan pada kualitas tenaga kerja, yang dapat dilihat dari tingkat pendidikan yang diukur dengan lama menempuh pendidikan. Masih rendahnya tingkat pendidikan penduduk akan menyebabkan rendahnya kualitas dan kuantitas output yang diproduksi produsen dan secara langsung akan berdampak pada rendahnya penyerapan tenaga kerja di sektor tersebut (Buchari, 2016). Menurut Nowak \& Gangadhar (2006), tingkat pendidikan mempengaruhi pertumbuhan ekonomi, maka dari itu pemerintah menjaga pendidikan pada prioritas utama dalam kebijakan publik. Pendidikan adalah faktor utama untuk meningkatkan pertumbuhan ekonomi dengan meningkatkan ketrampilan dan pengetahuan manusia yang akan meningkatkan produktivitas dan kompetensi (Hanif \& Noman, 2016).

Untuk menjamin kesejahteraan dan melindungi para pekerja agar keuntungan tidak hanya dinikmati pengusaha saja, maka pemerintah menetapkan upah minimum yang harus dibayarkan pengusaha kepada buruh sehingga dapat tercipta pemerataan distribusi pendapatan. Menurut Castro dkk, (2014) tingkat upah akan mempengaruhi pertumbuhan ekonomi. Dalam teori klasik pertumbuhan ekonomi, modal adalah faktor utama untuk mendorong pertumbuhan ekonomi. Modal dapat berasal dari investasi baik dari dalam negeri maupun modal dari luar negeri (Fazaalloh, 2019). Menurut Arestis \& Carolina (2017), efek dari investasi akan menpengaruhi pertumbuhan ekonomi. Oleh karena itu setiap Negara perlu meningkatkan investasi sehingga akan mendorong pertumbuhan ekonomi. 
Tabel 1.

Mengenai Laju Pertumbuhan Ekonomi Menurut Kab/Kota Di Provinsi Bali Tahun 2011 - 2018

\begin{tabular}{lllllllll}
\hline Kabupaten/Kota & \multicolumn{9}{c}{ Laju Pertumbuhan Ekonomi Menurut Kabupaten/Kota (Persen) } \\
& $\mathbf{2 0 1 1}$ & $\mathbf{2 0 1 2}$ & $\mathbf{2 0 1 3}$ & $\mathbf{2 0 1 4}$ & $\mathbf{2 0 1 5}$ & $\mathbf{2 0 1 6}$ & $\mathbf{2 0 1 7}$ & $\mathbf{2 0 1 8}$ \\
\hline Jembrana & 5.89 & 6.11 & 5.69 & 6.05 & 6.19 & 5.96 & 5.29 & 5.59 \\
Tabanan & 6.11 & 6.12 & 6.45 & 6.53 & 6.19 & 6.14 & 5.37 & 5.72 \\
Badung & 7.07 & 7.64 & 6.82 & 6.98 & 6.24 & 6.81 & 6.09 & 6.75 \\
Gianyar & 7.15 & 7.08 & 6.82 & 6.8 & 6.3 & 6.31 & 5.48 & 6.01 \\
Klungkung & 6.11 & 6.25 & 6.05 & 5.98 & 6.11 & 6.28 & 5.32 & 5.5 \\
Bangli & 6.14 & 6.2 & 5.94 & 5.83 & 6.16 & 6.24 & 5.33 & 5.5 \\
Karangasem & 5.43 & 5.93 & 6.16 & 6.01 & 6 & 5.92 & 5.08 & 5.48 \\
Buleleng & 6.44 & 6.78 & 7.15 & 6.96 & 6.07 & 6.02 & 5.39 & 5.62 \\
Denpasar & 7.16 & 7.51 & 6.96 & 7 & 6.14 & 6.51 & 6.06 & 6.41 \\
Provinsi Bali & 6.66 & 6.96 & 6.69 & 6.73 & 6.03 & 6.33 & 5.57 & 6.35 \\
\hline
\end{tabular}

Sumber : BPS Provinsi Bali, 2019

Pada Tabel 1 dapat diketahui Laju pertumbuhan ekonomi menurut kab/kota di provinsi bali pada tahun 2011 - 2018. Laju pertumbuhan di tiap kab/kota selalu mengalami fluktuasi tiap tahunnya. Pertumbuhan ekonomi berdasarkan kabupaten/ kota yang tertinggi terjadi di Kabupaten Badung pada tahun 2012 sebesar 7,64\% sedangkan pertumbuhan ekonomi terendah terjadi di Kabupaten Karangasem sebesar 5,8 pada tahun 2017.

Penduduk yang bertambah dari waktu ke waktu dapat menjadi pendorong maupun penghambat pertumbuhan ekonomi. Peningkatan jumlah penduduk akan memperbesar jumlah tenaga kerja dan penambahan tersebut memungkinkan suatu daerah untuk menambah produksi untuk memenuhi pasar domestik yang meningkat. Namun di sisi lain, akibat buruk dari pertambahan jumlah penduduk adalah kelebihan jumlah penduduk yang tidak diimbangi dengan faktor produksi 
yang tersedia dimana penambahan penggunaan tenaga kerja tidak akan menimbulkan penambahan dalam tingkat produksi.

Berdasarkan latar berlakang masalah, maka dapat dirumuskan masalah sebagai berikut : 1) Bagaimana pengaruh tingkat pendidikan, UMK dan Investasi terhadap penyerapan tenaga kerja di Provinsi Bali. 2) Bagaimana pengaruh tingkat pendidikan, UMK, investasi dan penyerapan tenaga kerja terhadap pertumbuhan ekonomi di Provinsi Bali. 3) Adakah pengaruh tidak langsung tingkat pendidikan, UMK dan investasi terhadap pertymbuhan ekonomi melalui penyerapan tenaga kerja di Provinsi Bali.

Tujuan penelitian ini adalah 1) Untuk menganalisis pengaruh tingkat pendidikan, upah minimum kabupaten/kota (UMK), dan Investasi terhadap penyerapan tenaga kerja di Provinsi Bali. 2) Untuk menganalisis pengaruh tingkat pendidikan, upah minimum kabupaten/kota (UMK), Investasi dan penyerapan tenaga terhadap pertumbuhan ekonomi di Provinsi Bali. 3) Untuk menganalisis pengaruh tidak langsung tingkat pendidikan, upah minimum kabupaten/kota (UMK) dan Investasi terhadap pertumbuhan ekonomi melalui penyerapan tenaga kerja di Provinsi Bali.

\section{METODE PENELITIAN}

Penelitian ini berbentuk kuantitatif dan bersifat asosiatif dengan bentuk hubungan kausal. Penelitian asosiatif digunakan untuk mengetahui pengaruh atau hubungan antara dua variabel atau lebih (Sugiyono,2012). Dalam penelitian ini penelitian asosiatif digunakan untuk mengetahui Pengaruh tingkat pendidikan, UMK, investasi terhadap penyerapan tenaga kerja dan pertumbuhan ekonomi di 
Provinsi Bali. Penelitian dilakukan di Provinsi Bali dengan menggunakan datadata yang dikeluarkan Badan Pusat Statistik dan dinas yang terkait dengan objek penelitian. Provinsi Bali dipilih karea pertumbuhan ekonomi kabupaten/ kota di Provinsi Bali berfluktuasi setiap tahunnya. Obyek Penelitian ini memfokuskan kajian pada lima variabel utama yaitu pertumbuhan ekonomi, penyerapan tenaga kerja, investasi, UMK, tingkat pendidikan

Data yang digunakan adalah data kuantitatif dan data kualitatif yang berdasar dari sekunder. Dalam penelitian ini data kuantitatif yang digunakan adalah pertumbuhan ekonomi, penyerapan tenaga kerja, tingkat pendidikan, UMK dan investasi di Provinsi Bali. Dalam penelitian ini yang berupa data kualitatif yang digunakan adalah teori-teori dan penjelasan mengenai pertumbuhan ekonomi, penyerapan tenaga kerja, tingkat pendidikan, UMK dan investasi di Provinsi Bali. Data sekunder yang digunakan oleh peneliti yaitu adalah data pertumbuhan ekonomi, penyerapan tenaga kerja, tingkat pendidikan, UMK dan investasi di Provinsi Bali.. Data dalam penelitian ini diperoleh dari BPS Provinsi Bali dan literatur-literatur lain yang mendukung mengenai objek penelitian. Metode pengumpulan data yang dilakukan adalah metode observasi.

Penelitian ini dilakukan di sembilan Kabupaten/Kota di Provinsi Bali, dari tahun 2014 - 2018. Metode analisis yang digunakan pada penelitian ini adalah analisis jalur (path analysis). Analisis ini juga digunakan untuk mengetahui hubungan langsung variabel independent terhadap variabel dependent dan hubungan yang tidak langsung melalui variabel intervening.

Persamaan regresi yang digunakan dalam penelitian ini adalah, sebagai berikut : 
$\mathrm{Y}_{1}=\beta 1 \mathrm{X} 1+\beta 2 \mathrm{X} 2+\beta 3 \mathrm{X} 3+\mathrm{e} 1$

$\mathrm{Y} 2=\beta 1 \mathrm{X} 1+\beta 2 \mathrm{X} 2+\beta 3 \mathrm{X} 3+\beta 4 \mathrm{Y} 1+\mathrm{e} 2$

Keterangan

$\mathrm{Y}_{2} \quad=$ Pertumbuhan Ekonomi

$\mathrm{Y}_{1} \quad=$ Penyerapan Tenaga Kerja

$\mathrm{X}_{1} \quad=$ Tingkat Pendidikan

$\mathrm{X}_{2} \quad=$ Upah Minimum Kabupaten/kota (UMK)

$\mathrm{X}_{3} \quad=$ Investasi

$\beta_{1} \ldots \beta_{3}=$ Koefisien regresi untuk masing-masing variabel $X$

$\mathrm{e}_{1}, \mathrm{e}_{2}=$ error

Berdasarkan persamaan regresi maka gambar konseptual penelitian dapat digambarkan sebagai berikut:

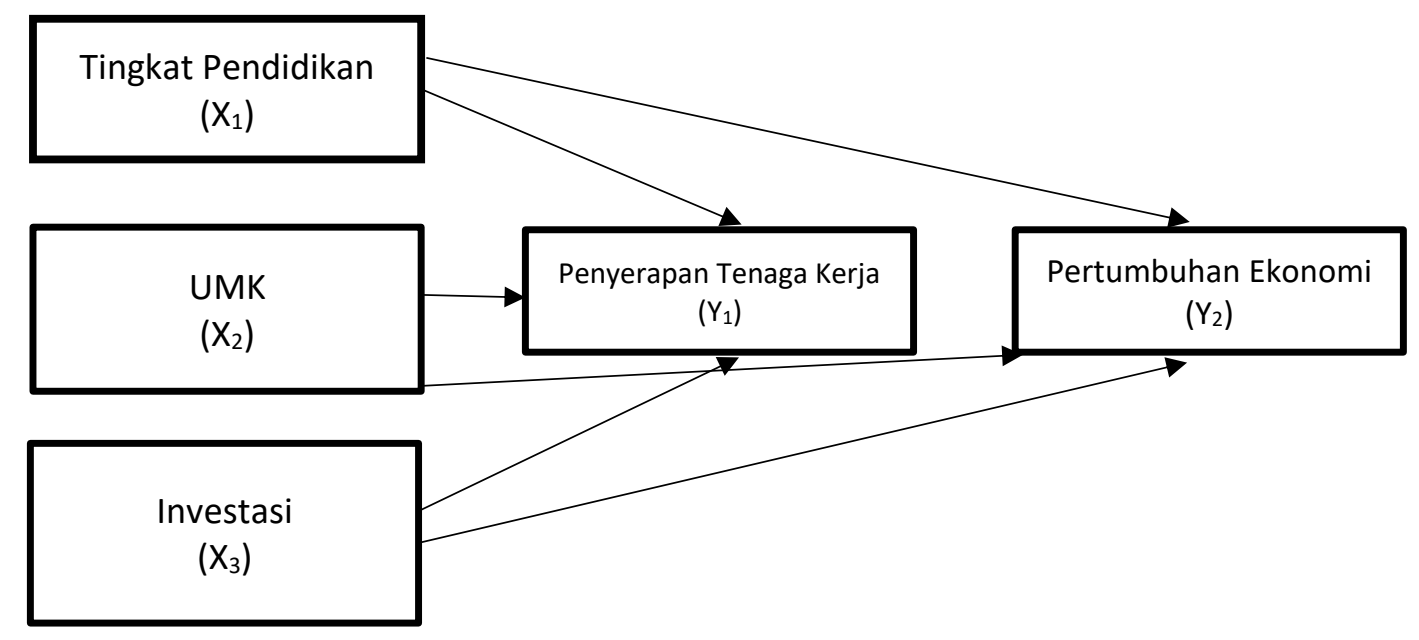

Gambar 1.

Pengaruh Tingkat Pendidikan, UMK, Investasi terhadap Penyerapan Tenaga Kerja dan Pertumbuhan Ekonomi Kabupaten/Kota di Provinsi Bali

Berdasarkan Gambar 1 dapat dilihat anak panah P1 menunjukan pengaruh secara tidak langsung antara variabel X1 terhadap Y2 melalui variabel intervening Y1. Pada anak panah P4 menunjukan pengaruh antara X1 secara langsung terhadap Y2. Pada anak panah P2 menunjukan pengaruh antara variabel X2 secara tidak langsung terhadap Y2 melalui variabel intervening Y1.Anak panah P5 
menunjukan pengaruh langsung antara variabel X2 terhadap Y2. Anak panah P3 menunjukan pengaruh tidak langsung antara variabel X3 terhadap Y2 melalui variabel intervening Y1. Anak panah P6 menunjukkan pengaruh langsung variabel X3 terhadap Y2. Dan anak panah P7 menunjukkan pengaruh langsung Y terhadap Y2.

\section{HASIL DAN PEMBAHASAN}

Tabel 2 menunjukkan hasil uji regresi Tingkat Pendidikan, UMK dan Investasi Terhadap Penyerapan Tenaga Kerja

Tabel 2.

Hasil Uji Regresi Tingkat Pendidikan, UMK, Investasi dan Penyerapan Tenaga Kerja Terhadap Pertumbuhan Ekonomi

\section{Coefficients $^{\mathrm{a}}$}

\begin{tabular}{|c|c|c|c|c|c|}
\hline \multirow[t]{2}{*}{ Model } & \multicolumn{2}{|c|}{$\begin{array}{l}\text { Unstandardized } \\
\text { Coefficients }\end{array}$} & \multirow{2}{*}{$\begin{array}{l}\text { Standardized } \\
\text { Coefficients } \\
\text { Beta }\end{array}$} & \multirow[t]{2}{*}{$\mathrm{t}$} & \multirow[t]{2}{*}{ Sig. } \\
\hline & B & Std. Error & & & \\
\hline (Constant) & 95.301 & .635 & & 150.093 & .000 \\
\hline T.Pendidikan & -.033 & .066 & -.070 & -.495 & .623 \\
\hline UMK & 1.650E-006 & .000 & .649 & 5.188 & .000 \\
\hline Investasi & $-8.047 \mathrm{E}-008$ & .000 & -.315 & -2.270 & .029 \\
\hline
\end{tabular}

a. Dependent Variable: P.TenagaKerja

Sumber: Data Diolah, Output Spss

Berdasarkan Tabel 2 menunjukkan bahwa tingkat pendidikan dengan nilai sig. $0.623>0.05$ menunjukkan bahwa tingkat pendidikan berpengaruh tidak signifikan dan memiliki pengaruh negatif terhadap penyerapan tenaga kerja. 
Menurut Sihombing (2017), tingkat pendidikan yang tidak berpengaruh signifikan terhadap penyerapan tenaga kerja salah satunya disebabkan oleh kondisi masyarakat yang semakin berpendidikan tidak diimbangi dengan tersedianya lapangan pekerjaan atau kesempatan kerja yang tersedia.

Sedangkan UMK dengan nilai sig. $0.000<0.05$ menunjukkan bahwa UMK berpengaruh signifikan dan memiliki pengaruh positif terhadap penyerapan tenaga kerja. Hasil penelitian ini didukung oleh penelitian sebelumnya, Rochmani, dkk (2016) yang menyatakan pengaruh UMK terhadap Penyerapan Tenaga Kerja adalah positif. Ini artinya naiknya upah inimum akan meningkatkan penyerapan tenaga kerja begitu juga sebaliknya, turunya upah mínimum akan menurunkan jumlah penyerapan tenaga kerja. Teori hubungan upah minimun dan penyerapan tenaga kerja menjelaskan bahwa pemberlakuan upah mínimum dapat menyebabkan pengangguran, namun dalam beberapa kasus pemberlakuan upah mínimum ini dapat menyebabkan perusahaan meningkatkan masukan tenaga kerja untuk meningkatkan hasil produksi sehingga dapat memaksimalkan laba.

Investasi dengan sig. $0,029<0,05$ menunjukkan bahwa investasi berpengaruh singnifikan dan memiliki pengaruh negatif terhadap penyerapan tenaga kerja. Menurut Budiarto dan Heni (2015) yang menyatakan invetasi berpengaruh negatif dan signifikan terhadap penyerapan tenaga kerja. Hal ini disebabkan karena pemilik usaha, menggunakan investasinya membeli barang modal dalam bentuk mesin-mesin untuk mendukung proses produksi sehingga lebih efektif dan efisien. Ini berarti pengggunakan tenaga kerja jumlahnya sangat 
rendah digunakan dalam proses produksi, sehingga dapat dikatakan penyerapan tenaga kerja rendah

Tabel 3 menunjukkan hasil uji regresi Tingkat Pendidikan, UMK dan Investasi Terhadap Penyerapan Tenaga Kerja

Tabel 3.

Hasil Uji Regresi Tingkat Pendidikan, UMK, Investasi dan Penyerapan

Tenaga Kerja Terhadap Pertumbuhan Ekonomi

\section{Coefficients $^{\mathrm{a}}$}

\begin{tabular}{|c|c|c|c|c|c|}
\hline \multirow[t]{2}{*}{ Model } & \multicolumn{2}{|c|}{$\begin{array}{l}\text { Unstandardized } \\
\text { Coefficients }\end{array}$} & \multirow{2}{*}{\begin{tabular}{|l}
$\begin{array}{l}\text { Standardized } \\
\text { Coefficients }\end{array}$ \\
Beta
\end{tabular}} & \multirow[t]{2}{*}{$\mathrm{t}$} & \multirow[t]{2}{*}{ Sig. } \\
\hline & $\mathrm{B}$ & Std. Error & & & \\
\hline (Constant) & -15.335 & 9.115 & & -1.682 & .100 \\
\hline T.Pendidikan & .193 & .040 & .621 & 4.783 & .000 \\
\hline UMK & $\begin{array}{l}-1.383 \mathrm{E}- \\
006\end{array}$ & .000 & -.810 & -5.522 & .000 \\
\hline Investasi & $\begin{array}{l}8.705 E- \\
009\end{array}$ & .000 & .051 & .378 & .707 \\
\hline P.TenagaKerja & .228 & .096 & .340 & 2.391 & .022 \\
\hline
\end{tabular}

a. Dependent Variable: PertumbuhanEkonomi

Sumber: Data Diolah, Output Spss

Berdasarkan Tabel 3 menunjukkan bahwa tingkat pendidikan dengan nilai sig. $0.000<0.05$ menunjukkan bahwa tingkat pendidikan berpengaruh signifikan dan memiliki pengaruh positif terhadap pertumbuhan ekonomi. Hal ini didukung oleh penelitian Indrasari, (2009) yang menyatakan menyatakan apabila seseorang yang tingkat pendidikannya lebih tinggi, dan lamanya dalam menempuh pendidikan akan memiliki pekerjaan dan upah yang lebih baik dibandingkan dengan pendidikannya yang lebih rendah. Apabila upah pekerja mencerminkan 
produktivitas, maka semakin banyak penduduk yang memiliki pendidikan tinggi, maka semakin tinggi produktivitas dan ekonomi nasional akan tumbuh dengan baik.

UMK dengan nilai sig. $0.000<0.05$ menunjukkan bahwa UMK berpengaruh signifikan dan memiliki pengaruh negatif terhadap pertumbuhan ekonomi. Menurut Panjawa dan Dariono (2014) menyatakan dengan meningkatnya tingkat upah menyebabkan terjadinya peningkatan biaya produksi perushaan yang akan berdampak pada pengurangan tenaga kerja dalam suatu perusahaan. Pengurangan tenaga kerja akan mempengaruhi kuantitas produkproduk yang di produksi sehingga akan mempengaruhi jumlah barang dan jasa yang dihasikan dari semua kegiatan perekonomian (PDRB) yang selanjutnya akan mempengaruhi pertumbuhan ekonomi.

Investasi dengan sig. 0,707 $>0,05$ menunjukkan bahwa investasi berpengaruh tidak singnifikan dan memiliki pengaruh positif terhadap pertumbuhan ekonomi. Hal ini Didukung oleh penelitian Hellen, dkk (2017) menyatakan adanya berpengaruh yang tidak signifikan antara variabel investasi dengan pertumbuhan ekonomi. Hasil ini mengindikasikan bahwa investasi belum mampu mendorong atau meningkatkan pertumbuhan ekonomi secara maksimal melalui nilai Produk Domestik Regional Bruto (PDRB).

Penyerapan tenaga kerja dengan sig $0.022<0.05$ menunjukkan penyerapan tenaga kerja berpengaruh signifikan dan memiliki pengaruh positif terhadap pertumbuhan ekonomi. Hal ini didukung oleh penelitian dari Arifin, (2010) yang menyatakan penyerapa tenaga kerja dan pertumbuhan ekonomi 
memiliki hubungan yang bersifat satu arah, ini berarti penyerapan tenaga kerja berpengaruh terhadap pertumbuhan ekonomi. Ekonomi dikatakan mengalami pertumbuhan apabila produksi barang dan jasa meningkat dari tahun sebelumnya. Semakin banyak masyarakat yang terserap pada lapangan pekerjaan semakin banyak produksi barang dan jasa yang dapat dihasilkan. hal ini tentu akan mempengaruhi PDRB tersebut yang mencerminkan kondisi pertumbuhan ekonomi pada daerah tersebut.

Oleh karena $\mathrm{Z}$ hitung sebesar $-1,034<1,64$ Artinya penyerapan tenaga kerja bukan sebagai variabel intervening pengaruh tidak langsung tingkat pendidikan terhadap pertumbuhan ekonomi di kabupaten/kota Provinsi Bali. Oleh karena $\mathrm{Z}$ hitung sebesar 3,559 >1,64. Artinya penyerapan tenaga kerja sebagai variabel intervening pengaruh tidak langsung UMK terhadap pertumbuhan ekonomi di Provinsi Bali. Oleh karena Z hitung sebesar -3,570 $<1,64$. Artinya penyerapan tenaga kerja $\left(\mathrm{Y}_{1}\right)$ tidak sebagai variabel intervening pengaruh tidak langsung investasi $\left(\mathrm{X}_{3}\right)$ terhadap pertumbuhan ekonomi $\left(\mathrm{Y}_{2}\right)$ di Provinsi Bali.

\section{SIMPULAN DAN SARAN}

Berdasarkan hasil analisis yang telah diuraikan pada bab sebelumnya maka dapat ditarik kesimpulan untuk menjawab rumusan masalah yakni sebagai berikut; (1) Tingkat pendidikan tidak berpengaruh signifikan terhadap penyerapan tenaga kerja di kabupaten/kota Provinsi Bali. UMK berpengaruh positif dan signifikan terhadap penyerapan tenaga kerja. Investasi berpengaruh negatif dan signifikan terhadap penyerapan tenaga kerja di kabupaten/kota Provinsi Bali; (2) Tingkat 
Pendidikan berpengaruh positif dan signifikan terhadap pertumbuhan ekonomi di kabupaten/kota Provinsi Bali. UMK berpengaruh negatif dan signifikan terhadap pertumbuhan ekonomi di kabupaten/kota Provinsi Bali. Investasi tidak berpengaruh signifikan terhadap pertumbuhan ekonomi di kabupaten/kota Provinsi Bali. Penyerapan tenaga kerja berpengaruh langsung dan signifikan terhadap pertumbuhan ekonomi di Provinsi Bali; (3) UMK berpengaruh tidak langsung terhadap pertumbuhan ekonomi melalui penyerapan tenaga kerja yang ditunjukkan dengan penyerapan tenaga kerja sebagai variabel intervening. Sedangkan tingkat pendidikan dan investasi tidak berpengaruh tidak langsung terhadap pertumbuhan ekonomi melalui penyerapan tenaga kerja yang ditunjukkan penyerapan tenaga kerja bukan sebagai variabel intervening.

Berdasarkan simpulan yang telah diuraikan maka dapat diajukan saran sebagai berikut; (1) Dalam hal investasi pemerintah sebaiknya melakukan kebijakan dengan mendorong industry padat karya melihat banyaknya tenaga kerja yang bisa terserap dalam lapangan pekerjaan dan mengurangi dana investasi yang hanya digunakan untuk industri padat modal yang lebih mempergunaakan investasi untuk membeli mesin-mesin sehingga akan berdampak pada pengurangan penggunaan tenaga kerja; (2) Pemerintah diharapkan mampu meningkatkan investasi baik dalam PMDN maupun PMA melalui kebijakankebijakan dalam bidang ekonomi, politik maupun kemanan dalam negeri, perbaikan infrastruktur dalam menunjang perekonomian, serta mempermudah regulasi dalam berinvestasi; (3) Untuk memaksimalkan peran pendidikan dalam pertumbuhan ekonomi sebaiknya, baik pihak pemerintah maupun swasta dapat 
memberikan pelatihan-pelatihan yang dibutuhkan dalam dunia kerja kepada masyarakat sehingga dapat meningkatkan produktifitas mereka.

\section{REFERENSI}

Akan, Yusuf, Ibrahim Arslan, Cem Is K. 2007. The Impact of Tourism on Economic Growth: The Case of Turkey. Journal of Tourism Volume IX

Arestis, Philip \& Carolina Troncosso Baltar. 2017. Income Distribution and Economic Growth : A Critical Approach. PANOECONOMICUS, Vol.64 Issue 2

Beard, T. Randolph, George S. Ford, Hyeongwoo Kim. 2018. Communication Policy and Employment Effect In The Information Sector. Phoenix Center Policy Buletin

Buchari, Imam. 2016. Pengaruh Upah Minimum dan tingkat Pendidikan Terhadap Penyerapan Tnaga Kerja Sektor Industri Manufaktur di Pulau Sumatera Tahun 2012-2015. E-Journal STIE Dewantara, Vol. 11 no.1

Budiarto, Arif dan Made Heni Urmila Dewi.2015.Pengaruh PDRB dan Upah Minimum Provinsi Terhadap Penyerapa Tenaga Kerja Melalui Mediasi Investasi di Provinsi Bali. E-Jurnal EP Unud. Vol.4 Hal. 1219-1246

Castro, Gerardo Angeles, Jonatan Juarez Cruz, Miguel Flores Ortega. 2014. The Effect of Average Wages on The Economy : The Case of United States. International Journal of Bussiness and Sosial Science, Vol.5 No.1

Cooray, Arusha. 2018. The Role Of Education In Economic Growth. SSRN Electronic Journal

Darma, Nazifi Abdullahi. 2014. Federal Capital Expenditure and Its Impact on Economic Growth in Nigeria; 1980-2010. Developing Country Studies Vol. 4 No.4

Fazaalloh, Al Muizzudin. 2019. Penanaman Modal asing dan Pertumbuhan Ekonomi di Indonesia : Suatu Analisis Kausalitas. JEKT, Vol. 12 No.1

Ganie, Djupiansyah. 2017. Analisis Pengaruh Upah, Tingkat Pendidikan, jumlah penduduk, dan PDRB Terhadap Penyerapan Tenaga Kerja di Kabupaten Berau Kalimantan Timur. Jurnal Eksekutif, Vol. 14 No.2 
Hanif, Nadia \& Noman Arshed. 2016. Relationship Between School Education and Economic Growth: SAARC Countries. International Journal of Aconomic and Financial Issues

Hellen, Sri Mintarti, Fitriadi. 2017. Pengaruh Investasi dan Tenaga Kerja Serta Pengeluaran Pemerintah Terhadap Pertumbuhan Ekonomi dan Kesempatan Kerja. INOVASI. Vol.13 (1)

Kotaskova, Sylvie Kobzev. Petr Prochazka, Lubos Smutka, Mansoor Maitah, Elena Kuzmenko, Marketa Kopecka, Vladimir Honig. 2018. The Impact Of Education on Economic Growth : The Case Of India. Acta Universitatis Agriculturae Et Silviculturae Memdelianae Brunensis Vol. 66 No.1

Nowak, A.Z., \& Gangadhar Dahal. 2016. The Contribution of Education to Economic Growth : Evidence From Nepal. International Journal of Economic Science, Vol. 5 No.2

Panjawa, Jihad Lukis, Daryono Soebagiyo. 2014. Efek Peningkatan Upah Minimum Terhadap Tingkat Pengangguran. Jurnal Ekonomi dan Studi Pembangunan. Vol.15, No.1

Pratomo, Devanto Shasta. 2017. Pendidikan dan Partisipasi Angkatan Kerja Wanita di Indonesia : Analisis Terhadap Hipotesis Kurva U. JEKT, Vo. 10 No.2

Sihombing, Fransisca Natalia. 2017. Kontribusi Tingkat Pendidikan da Upah Minimum Terhadap Penyerapan Tenaga Kerja di Kota Medan Tahun 20122015. Jurnal Pembangunan Perkotaan, Vol.5 No.1

Sugiyono. 2013. Stastitik Untuk Penelitian. Bandung : Alfabeta

Suyana Utama, Made. 2009. Buku Ajar Aplikasi Analisis Kuantitatif. Denpasar: Sastra Utama.

Trisnu, Cok Istri Sinta Regina \& Ida Bagus Putu Purbadharmaja. 2014. Pengaruh PMDN dan PMA Terhadap PDRB Di Provinsi Bali. E-Jurnal Ekonomi Pembangunan Universitas Udayana Vol. 3, No. 3,

Wijaya, Andi, Toti Indrawati Eka Armas Pailis. 2014. Analisis faktor-faktor yang mempengaruhi penyerapan tenaga kerja di Provinsi Riau. Jom FEKON Vol. 1 No. 2

Xu, Shanying, Lin Huo, Wei Shang. 2015. The Impact of Wage Distribution on Economic Growth Based on Multi-Agent Simulation. Procedia Computer Science, Vol 55 Page 809-817 
Ida Bagus Agung Bayu windayana dan Ida Bagus Darsana. Pengaruh Tingkat Pendidikan

Yanthi, Cokordo Istri Dian Purnama \& A.A.I.N Marhaeni. 2015. Pengaruh Pendidikan, Tingkat Upah dan Pengangguran Terhadap Persentase Penduduk Miskin di Kabupaten/Kota Provinsi Bali. PIRAMIDA, Vol.11 No.2

Yusuf, Arief Anshory \& Andy Sumner. 2015. Growth, Poverty and Inequality Under Jokowi. Bulletin of Indonesian Economic Studies, Vol. 51 No.3 